\title{
Analysis of Antioxidant Effects of Lycopene and Caffeine in Experimentally Induced Renal Ischemia-Reperfusion Injury in Rats
}

\section{Ratlarda Deneysel Olarak Oluşturulan Renal İskemi-Reperfüzyon Hasarında Likopen ve Kafeinin Antioksidan Etkilerinin Incelenmesi}

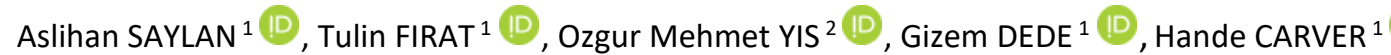

\begin{abstract}
${ }^{1}$ Bolu Abant Izzet Baysal University Medical Faculty, Histology and Embryology Department, Bolu, TURKEY
2 Bolu Abant Izzet Baysal University Medical Faculty, Biochemistry Department, Bolu, TURKEY
\end{abstract}

\begin{abstract}
Background: The aim was to investigate the antioxidant effects of lycopene and caffeine in rats exposed to renal ischemia/reperfusion (IR) injury.

Materials and Methods: Following right renal nephrectomy, 60 minutes of ischemia followed by 60 minutes of reperfusion were performed in 200-250 gram Wistar albino rats used in the study. 30 minutes before ischemia, lycopene $(5 \mathrm{mg} / \mathrm{kg})$, caffeine $(50 \mathrm{mg} / \mathrm{kg})$, lycopene $(5 \mathrm{mg} / \mathrm{kg})+$ caffeine $(50 \mathrm{mg} / \mathrm{kg})$ were administered intraperitoneally to the rats. After the experiment, $4 \mathrm{ml}$ of blood and left kidney were taken from the rats. Tissue malondialdehyde (MDA), glutathione peroxidase (GSH-Px), superoxide dismutase (SOD) and serum creatinine activities were measured biochemically and light microscopy findings were evaluated histologically.

Results: When MDA levels are compared; Although the MDA level of the IR+Lycopene group was lower than the IR group, no significance was observed. When IR+Lycopene and IR+Caffeine groups are compared; The MDA level of the IR+Lycopene group is higher than the IR+Caffeine group. In the IR+Caffeine group; A statistically significant increase was observed in serum creatinine compared to the IR+Lycopene+Caffeine group. Although SOD and GSH-Px were higher in the antioxidant groups compared to the IR group, no statistically significant difference was observed. When compared with ischemia-reperfusion group, histopathological damage was found to be significantly lower than in the other groups. It was found that Lycopene and Caffeine reduced apoptosis, tubular dilatation, tubular epithelium degeneration, glomerular shrinkage, desquame epithelium and proteinous cast amount significantly.

Conclusions: While lycopene has high antioxidant efficiency when compared with caffeine, lycopene and caffeine have protective effect against renal ischemia reperfusion injury.
\end{abstract}

Key Words: Kidney, Ischemia/Reperfusion Injury, Lycopene, Caffeine

Öz.

Amaç: Renal iskemi/reperfüzyon hasarına maruz kalmış ratlarda likopen ve kafeinin antioksidan etkilerinin incelenmesi amaçlandı.

Materyal ve Metod: Çalışmada kullanılan 200-250 gram Wistar albino cinsi erkek ratlara sağ renal nefroktomi sonrası $60 \mathrm{dk}$ iskemi ve bunu takiben $60 \mathrm{dk}$ reperfüzyon gerçekleştirildi. İskemiden $30 \mathrm{dk}$ önce ratlara Likopen $(5 \mathrm{mg} / \mathrm{kg})$, kafein $(50 \mathrm{mg} / \mathrm{kg})$, Likopen $(5 \mathrm{mg} / \mathrm{kg})+$ kafein $(50 \mathrm{mg} / \mathrm{kg})$ intraperitoneal olarak uygulandı. Deney sonrası ratlardan $4 \mathrm{ml}$ kan ve sol böbrek alındı. Biyokimyasal olarak doku malondialdehit (MDA), glutatyon peroksidaz (GSH-Px), süperoksit dismutaz (SOD), serum kreatinin aktiviteleri ölçüldü ve histolojik olarak ışık mikroskobi bulguları değerlendirildi.

Bulgular: MDA seviyeleri karşılaştırıldığında; IR+Likopen grubunun MDA seviyesi, IR grubuna göre düşük çıkmasına rağmen anlamlılık gözlenmemiştir. IR+Likopen ile IR+Kafein grubu karşılaştırıldığında ise; IR+Likopen grubunun MDA seviyesi IR+Kafein grubuna göre daha yüksektir. IR+Kafein grubunda; IR+Likopen+Kafein grubuna göre serum kreatinin bakımından istatistiksel olarak anlamlı bir artış gözlenmiştir. SOD ve GSH-Px ise IR grubuna göre antioksidan gruplarda yüksek olmasına rağmen istatistiksel olarak anlamlı bir farklılık gözlenmemiştir. Histopatolojik hasar; iskemi-reperfüzyon grubuyla karşılaştırıldığında diğer gruplarda anlamlı derecede düşük çıkmıştır. Likopen ve Kafein; apoptozis, tübüler dilatasyon, tübüler epitel dejenerasyonu, glomerüler büzülme, deskuame epitel ve proteinöz kast miktarını önemli ölçüde düşürmüştür.

Sonuç: Likopenin Kafeine göre antioksidan etkinliği yüksek olmakla birlikte likopen ve Kafeinin renal iskemi reperfüzyon hasarına karşı koruyucu etkisi vardır.

Anahtar kelimeler: Böbrek, İskemi/Reperfüzyon Hasarı, Likopen, Kafein

\section{Corresponding Author / Sorumlu Yazar}

Dr. Aslihan SAYLAN

Bolu Abant Izzet Baysal University

Medical Faculty,

Histology and Embryology Department, Bolu, TURKEY

E-mail: aasli.aasli@gmail.com

Received / Geliş tarihi: 20.01.2021

Accepted / Kabul tarihi: 17.12.2021

DOI: 10.35440/hutfd.865165 


\section{Introduction}

Ischemia is a condition related to oxygen and nutrient deficiency, characterized by decreased blood flow to the tissue. Reperfusion is a damage caused by restoring blood flow after a minimum of 10 minutes of ischemia $(1,2)$. Ischemiareperfusion (IR) is a common occurrence in conditions such as heart attack, organ transplantation, extremity injury and causes damage in many organs such as skeletal muscles, heart, brain and kidney $(1,3)$. Renal IR is one of the common causes of acute kidney injury, which occurs with a sudden decrease in blood flow to the kidneys. Despite advances in methods to prevent this situation, death rates are quite high $(4,5)$. Although reperfusion is essential for the repair of ischemic renal injury, it also causes damage. Reperfusion occurs in the tissue after the agents causing hypoxia are removed from the environment. Polymorphnuclear leukocytes migrate to the tissue, causing the formation of endothelial damage and excessive reactive oxygen species (ROS). Endoplasmic reticulum is damaged, leading to autophagosome formation and thus cellular lysis $(6,7)$. ROS formation caused by reperfusion after an ischemic attack plays an important role in the pathogenesis of acute ischemic renal failure. The increase in the levels of malondialdehyde, which is a marker of lipid peroxidation, has been found more frequently in perfusion after ischemic attack and antioxidants have shown a mitigating effect on tissue damage caused by ROS (7). There are no optimal protective agents preventing renal damage and reducing ischemic damage (7). Recently, anti-apoptotic chemicals, antioxidants, nuclear selective antagonists aiming IR treatment have been used $(2,8)$. 4 Lycopene is a lipophilic carotenoid with antioxidant properties. It is found mainly in tomato and also in other red fruit (9). It has been proven that lycopene has a large number of protective biological functions in aging, tissue damage and various diseases such as cancer types, atherosclerosis and coronary artery disease $(10,11)$. Lycopene protects the cell from lipid peroxidation and oxidative DNA damage due to its highly effective antioxidant properties. It also has anti-apoptotic, anti-inflammatory, anti-amyloid, anti-ischemic and antitumor properties (12). Lycopene increases ATP synthesis and ETS chain activity. It also protects the mitochondrial DNA from oxidative damage. Oxidative stress is very important in ischemic damage characterized by ROS increase. In normal cells, antioxidant system protects the cell from various oxidant stresses. In addition, due to its high lipid solvent properties, lycopene can cross the blood-brain barrier. It is also useful for neurological diseases such as Alzheimer $(10,12-13)$. Coffee is one of the most popular drinks in the world. An average of 6-7 million tons is consumed annually (15). Caffeine (1,3,7- trimethylxanthine) is a frequently used psychostimulant. It is frequently used for the treatment of headache, neonatal respiratory problems, obesity and hypotension. It has also been shown that caffeine has a strong antiinflammatory effect. Animal models have also shown that high doses of caffeine have significant therapeutical effect against traumatic brain damage. It has also been shown to have protective effects against myocardial IR damage (16). It has been proven that coffee is a strong antioxidant and it has a protective effect in tissues against $\operatorname{ROS}(17,18)$. In our study, we aimed to observe the protective effects of lycopene and caffeine, which have antioxidant effects, on renal IR injury.

\section{Materials and Methods Preparation of rats:}

Our study was carried out in accordance with the national health institute guidelines on the use of experimental animals with the permission of Bolu Abant Izzet Baysal University Animal Research Local Ethics Committee 2018/29 numbered permission. 2-4 months old and 250-270 gr weighing 42 Wistar albino male rats obtained from the experimental animals research and application centre were used. Rats which were kept separately in an environment with constant temperature $\left(24 \pm 2^{\circ} \mathrm{C}\right)$ and humidity $(55 \pm 15 \%)$ and were fed with standard rat pellet and water ad libitum.

\section{Experimental Model:}

The rats were grouped in 6 randomly and a total of 6 groups were studied as the control group, IR group, IR+Lycopene group, IR+Caffeine group, IR+ Lycopene+Caffeine group, and dimethylsulphoxide (DMSO) group. Caffeine (Lot:BCBW9292,USA), Lycopene (Lot:LRAA8328,USA), and DMSO (Lot:BCBV9470, USA) were purchased from SigmaAldrich. In the study which was performed under anaesthesia with $10 \mathrm{mg} / \mathrm{kg}$ xylazine and $90 \mathrm{mg} / \mathrm{kg}$ ketamine according to the body weights of rats, abdomen was dissected and renal nephrectomy was performed in the control group. In the IR group, the right kidney was removed and right renal artery and vein were clamped for 60 minutes. During ischemia, the abdomen was covered with gauze. Subsequently, reperfusion was provided for 60 minutes. During these periods, the body temperature or rats was maintained on heating plate (Figure 1).

In the IR+Lycopene group, $5 \mathrm{mg} / \mathrm{kg}$ Lycopene (19), in the $\mathrm{IR}+$ Caffeine group, $50 \mathrm{mg} / \mathrm{kg}$ Caffeine (16), in the IR+Lycopene+Caffeine group $5 \mathrm{mg} / \mathrm{kg}$ Lycopene and $50 \mathrm{mg} / \mathrm{kg}$ caffeine were given intraperitoneally in a volume of $1 \mathrm{ml}$ based on the body weights of rats 30 minutes before ischemia. In DMSO group, $2 \%$ DMSO was given intraperitoneally in a volume of $1 \mathrm{ml}$ based on the body weights of rats. After reperfusion, $4 \mathrm{ml}$ blood and left kidney were taken from the rats intracardially. Following this, the subjects were sacrificed using the whole blood collection method. After $4 \mathrm{ml}$ of blood was taken intracardially, the left kidney was dissected into two.

The first half was put in PBS solution for biochemical analysis and glutathione peroxidase (GSH-Px), malondialdehyde (MDA) superoxide dismutase (SOD) and serum creatinine values were checked in blood and tissue. The other half of the kidney was put in $10 \%$ formaldehyde solution and examined histopathologically and immunohistochemically. 


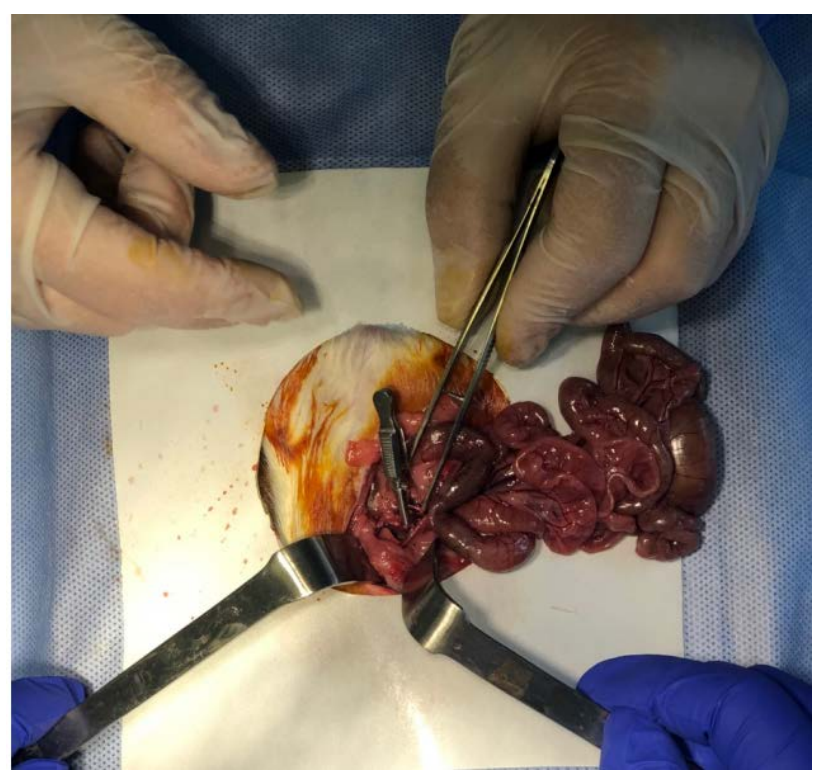

Figure 1. Forming the Renal Ischemia-Reperfusion Model

\section{Biochemical Analysis:}

Dry tubes with gel separator including clot activator (Vacuette, GreinerBio-oneGmbH, Kremsmünster, Austria) were used to obtain serum. Blood samples were centrifuged at $1250 \mathrm{x} g$ for ten minutes in the medical biochemistry laboratory of BAIBÜ Faculty of Medicine and their serums were separated. Aliquoted serums were stored in freezer (HERA Freeze, ThermoFisherScientific, Waltham, Massachusetts, $A B D$ ) at -80 o C. After the serum samples were thawed gradually, they were centrifuged at $1000 \times$ g at $4^{\circ} \mathrm{C}$ for 15 minutes. The resulting supernatant was used to work SOD, MDA, GSH-Px and creatinine. Cayman ELISA Kit (1180 E. EllsworthRd-AnnArbor, MI-USA) was used in SOD and MDA measurement, while CloudCloneCorp. ELISA Kit (23603 W.Fernhust Dr., Unit 2201, Katy, TX 77494 USA) commercial kits were used in MPO measurement. Serum creatinine measurement, picric acid, sodium dodecyl sulphate (SDS), sodium hydroxide, sodium phosphate, sodium tungstate and sulphuric acid measurements were made with chemicals provided from Merck company (E.Merck, Darmstadt, Germany); $\mathrm{HCl}$ and acetic acid measurements were made with chemicals provided from RiedeldeHaën (Sigma-Aldrich Labor chemikalienGmbH, Germany), Fuller's earth Sigma (Sigma Chemical Company Poole, Dorset, UK) and the absorbance of the orange colored compound formed by creatinine in picric acid and alkali environment by Jaffe reaction was measured at $520 \mathrm{~nm}$.

\section{Histopathological Analysis:}

For histopathological evaluation, kidney tissue in $10 \%$ formaldehyde solution was tracked histologically and embedded in paraffin blocks. $3 \mu \mathrm{m}$ thick sections taken from the blocks were placed on a slide and stained with Haematoxylin-Eosin (H\&E). Stained sections were analysed under a light microscope and evaluated in terms of inflammation, congestion, tubular dilation, desquamation, glomerular shrinkage and cast formation. In addition, Caspase 3 (ThermoScientific, UK, Lot:1510C) immunostaining was performed and apoptosis was examined. The changes were evaluated with quantitative measurements. Renal damage was scored as 0 = none; $1=10 \% ; 2=11 \%$ to $25 \% ; 3=26 \%$ to $45 \% ; 4=46 \%$ to $75 \%$; and $5=76 \%$ (20). Histopathological evaluation and apoptosis were performed as double blind by two histologists.

\section{Immunohistochemical Analysis:}

For immunohistochemical analysis, Caspase 3 (ThermoScientific, UK, Lot:1510C) stain was used. $3 \mu \mathrm{m}$ thick sections taken from the blocks were taken on a slide and $0.01 \mathrm{M}$ Phosphatebuffered saline (PBS) were washed 3 times for 5 min each. Following 20 min of treatment with hydrogen peroxide (Thermo Scientific, US,Lot:HP41515), it was washed again with PBS 3 times for 5 min each. To prevent non-specific staining, Caspase 3 , was dripped over the preparations of a ratio of $0,01 \mathrm{M}$ percent after dripping on the Ultra $\mathrm{V}$ Block (Thermoscientific,UK,Lot: AUB141116). After 5 min of washing with PBS, the secondary antibody (Biotinylated Goat Anti-polyvalent/Thermo Scientific, UK, Lot:PBN141111AE) was dripped and held for $10 \mathrm{~min}$ at room temperature. After washing with PBS, the Streptavidin Peroxidase (ThermoScientific, UK, Lot:SHR150121AA) was suspended for $10 \mathrm{~min}$ at room temperature. Examples were washed in distilled water after exposure to DAB solution for 5 min (ThermoScientific, UK,Lot:HDC36221). For contrast staining, Haematoxylin (Large Volume Mayer's Haematoxylin/ThermoScientific, USA, Lot:MH17753) was dripped for 30-45 s and then washed and held to dry at room temperature after dripping in distilled water. Apoptotic evaluation was made according to the severity of the staining of the kidney tissue.

\section{Statistical analysis:}

Data were analysed using SPSS 17.0 software program. The data used were expressed as mean \pm standard deviation. Differences in the data among groups which were normally distributed in the present study were assessed using One-Way ANOVA which is a parametric test followed by the Tukey's HSD test with post-hoc analysis to identify individual group differences. Kruskal-Wallis test was used for nonparametric comparison among groups which were not in the normal distribution. In this context, Tamhane's T2 test was used as a post hoc test. Differences were regarded as statistically significant at $p<0.05$.

\section{Results}

Control and DMSO groups looked normal histopathologically. In IR group, glomerular shrinkage, tubular dilation, desquame epithelium and proteinaceous cast and interstitial haemorrhage were observed. In IR+Lycopene, IR+Caffeine and IR+Lycopene+Caffeine groups, decrease was found in terms of injury. In IR+ Lycopene group, the rate of injury was found to be significantly lower when compared with the other groups $(p<0.05)$ ( Figure 2 ). 


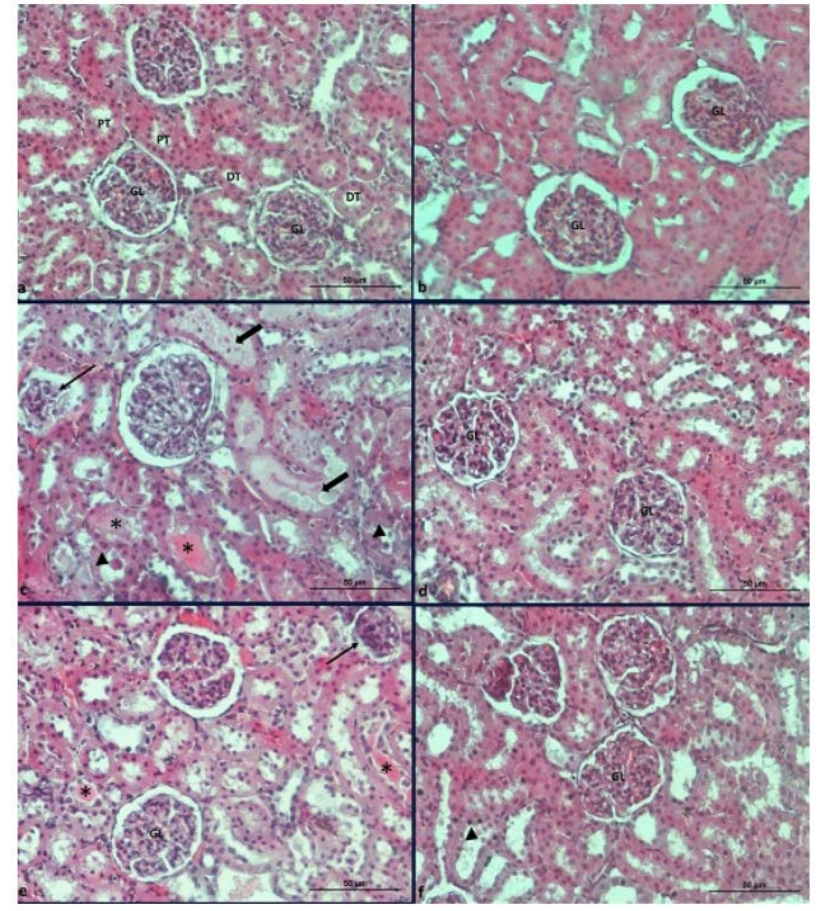

Figure 2. Control group Proximal tubule (PT), Distal Tubule (DT), Glomerulus (GL) normal appearance (a), DMSO group normal appearance (b), IR group glomerular shrinkage (thin arrow), tubular dilation (thick arrow), proteinaceous cast (star), desquame epithelium (arrow head) (c), Lycopene group close to normal appearance (d), Caffeine group proteinaceous cast (star), glomerular shrinkage (thin arrow) (e), Lycopene+Caffeine group desquame epithelium (arrow head). H\&E X200, Bar: $50 \mu \mathrm{m}$.

When the apoptosis in the groups was analysed; while control and DMSO groups showed a normal appearance; apoptosis was observed in $I R, I R+L y c o p e n e, I R+C a f f e i n e$ and $\mathrm{IR}+$ Lycopene+Caffeine groups. When apoptosis rates were compared, IR group was found to be significantly high $(p<0.05)$. IR+Lycopene group was found to be quite low in terms of apoptosis density when compared with the other groups. When IR+Caffeine and IR+Lycopene+Caffeine group were compared, apoptosis of IR+Caffeine group was found to be significantly higher when compared with $I R+L y c o p e n e$ group (Figure 3).

When MDA levels in groups were compared in the findings we obtained as a result of renal IR, although the MDA level of the IR+Lycopene group was lower than the IR group, no significance was observed.

When $I R+L y$ copene and $I R+C$ affeine groups are compared; The MDA level of the IR+Lycopene group is higher than the IR+ caffeine group. However, no statistical significance was found. Serum creatinine levels; It was statistically significantly higher in the IR+Lycopene group compared to the IR group $(p<0.05)$. In the IR+Caffeine group; A statistically significant increase was observed in serum creatinine compared to the $I R+$ Lycopene+Caffeine group $(p<0.05)$. Although SOD and GSH-Px were high in antioxidant groups, no statistically significant difference was found (Table 1).

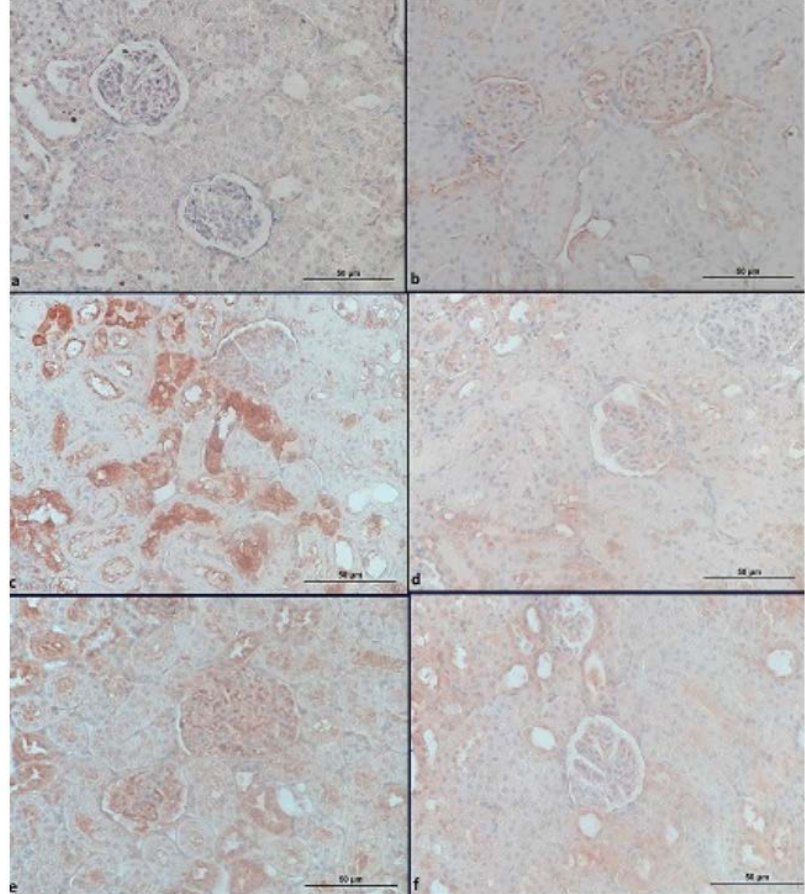

Figure 3. Caspase 3 immune staining. Control group (a), DMSO group mild staining (b), I-R group severe Caspase 3 activity when compared with staining severity (c), IR+Lycopene group close to normal caspase 3 activity (d), $\mathrm{IR}+$ Caffeine group more than normal Caspase 3 activity (e), IR+Lycopene+Caffeine group Caspase 3 activity a bit higher than IR+Lycopene. Bar: $50 \mu \mathrm{m}$

Table 1. Mean $\pm S D$ values of biochemical analyses for all groups

\begin{tabular}{lcccc}
\hline \multicolumn{5}{c}{ Mean \pm SD values } \\
\hline Groups & MDA & Kreatinin & SOD & GSH-Px \\
\hline Control & $1.802 \pm 2.698$ & $0.487 \pm 0.017$ & $20.334 \pm 5.523$ & $1.979 \pm 0.793$ \\
DMSO & $1.412 \pm 2.839$ & $0.902 \pm 0.054$ & $22.050 \pm 7.297$ & $3.660 \pm 1,119$ \\
IR & $1.896 \pm 5.573$ & $0.744 \pm 0.086$ & $20.050 \pm 10.998$ & $2.732 \pm 0.710$ \\
IR+Lycopene & $1.572 \pm 1.821$ & $0.921 \pm 0.128$ & $20.958 \pm 7.846$ & $2.572 \pm 0.981$ \\
IR+Caffeine & $1.387 \pm 2.815$ & $1.084 \pm 0.162$ & $23.712 \pm 4.353$ & $1.739 \pm 0.993$ \\
IR+Lycopene+Caffeine & $1.450 \pm 4.685$ & $0.867 \pm 0.036$ & $25.155 \pm 8.691$ & $3.267 \pm 0.548$ \\
\hline
\end{tabular}

\section{Discussion}

The aim of our study was to find out whether lycopene and caffeine protected the kidney in renal ischemia reperfusion injury by showing antioxidant effect. Our empirical findings showed that lycopene and caffeine decreased renal IR injury and reduced oxidative stress and apoptosis. Molecular mechanisms underlying IR injury have been studied extensively in recent years. Oxidative stress is an important cause of renal IR damage. ROS plays the most important role in this mechanism. When ischemic tissues reperfuse, more oxygen goes to the tissues and this causes extreme ROS formation. Extreme ROS results in tissue damage and apoptosis (21). Reactive molecules ROS includes can be produced naturally in the biological system. When ROS is produced in low levels, 
it acts as an important signal molecule in conditions such as immune response and muscle contraction. In addition, endogenous antioxidants such as catalase, SOD and glutathione peroxidase are important regulators that keep ROS in normal levels. Membrane lipids, nucleic acids and DNA are very sensitive to ROS. Excessive production of ROS causes protein, lipid and DNA peroxidation and accelerates IR damage by triggering mitochondrial cell death $(3,21-22)$. Lycopene, which is a member of the carotenoid family, is found predominantly in tomato and other red fruits $(24,25)$. Lycopene has a protective effect against oxidative damage caused by ROS in the DNA $(7,26)$. Rasheed et al. observed that lycopene given orally for 10 days to rats with acute kidney injury is a natural antioxidant that reduces the damage (27). In a study they conducted, Zhang et al. found that lycopene reduced MDA and $\mathrm{H} 2 \mathrm{O} 2$ level and increased antioxidant enzyme level (28). While a increase was found in MDA and Creatinine rates in our study, an increase was observed in SOD and Gpx levels. Our histological results proved the strong antioxidant effects of lycopene. In their hepatic IR study on rats, Bayramoglu et al. found that $5 \mathrm{mg} / \mathrm{kg}$ lycopene reduced IR damage (19). Koul et al. administered $5 \mathrm{mg} / \mathrm{kg}$ lycopene to rats in kidney damage with dexamethasone and observed a decrease in cell damage and oxidative stress markers (29). Our results are similar to the results of these studies. IR-induced acute kidney injury is an experimental and clinical syndrome characterized by large decline in glomerular filtration rate, diffuse glomerular impairment, severe tubular damage, tubular cell necrosis and signs of tubular occlusion with cell debris (5). Pektaş et al. examined the productivity of lycopene in IR injury with biochemical and histopathological parameters and found that lycopene showed an antioxidant effect (7). Hussien et al concluded that $10 \mathrm{mg} / \mathrm{kg}$ Lycopene supplement administered to rats played a protective role against renal ischemiareperfusion injury (30). Kaya et al. (31) used single dose lycopene in renal IR injury and when they examined the biochemical and histopathological parameters, they mentioned that lycopene administered before renal IR decreased renal injury. In a study they conducted on the effect of lycopene on renal IR injury, Sadic et al. (6) observed that lycopene reduces histopathological findings. In our study, lycopene reduced apoptosis, tubular dilation, tubular epithelium degeneration, glomerular shrinkage, desquame epithelium and proteinaceous cast rates. Bedir et al. reported that lycopene decreased the oxidative kidney damage caused by the application of isoniazid and rifampicin biochemically and histopathologically in rats, and that lycopene could be beneficial in the treatment of nephrotoxicity (32). In a study conducted on myocardioblasts, Chen et al. (10) found that lycopene provided a protective effect against cell apoptosis. As a result of our caspase 3 staining, our histopathological results show that lycopene decreases apoptosis in the cell. Caffeine, which is a purine alkaloid (1, 3, 7- trimetilksantin), is found in a few popular drinks such as coffee, tea and energy drinks.
Caffeine and other methylxanthines are also used as components of analgesics, appetite suppressants, muscle relaxants and stimulant drug formulations $(18,33)$. Some effects of caffeine may support the production of free radicals and later cause an increase in lipid peroxidation by increasing oxidative stress. More recent observations also show that it can also act as an antioxidant (34). Various studies argue that caffeine provides protection against cellular damage by creating antioxidant effects $(35,36)$. In one study, Lee et al. advocated that caffeine is a well-known hydroxyl radical scavenger (18). Kılıcdag et al. (37) observed caffeine reduced cellular apoptosis in hypoxic-ischemic brain damage in rats. In a study conducted to examine the antioxidant effect of caffeine against kidney damage in albino rats, caffeine was found to decrease renal toxicity (34). Nilnumkhum et al. examined the protective effect of caffeine against renal fibroblast activation caused by hypoxia and found that it decreased intracellular ROS (38). In a study conducted on ovarian cells, Fernandez et al. evaluated the anti-apoptotic and anti-oxidative effects of caffeine and thought that the effect was dose-dependent. They proved that low-dose caffeine did not lead to any damage (39). Al Moutaery et al. (40) showed that intraperitoneal administration of high dose caffeine in rats which underwent experimental head trauma increased lipid peroxidation in the cortex and caused oxidative stress. In a study conducted on the effects of caffeine on kidney functions, it was proven that there is an association between caffeine and lipid peroxidation and that caffeine decreased MDA levels (33). Our study concluded that caffeine decreased oxidative parameters in renal IR injury, but did not cause a statistically significant result. This was also supported by histopathological results.

\section{Conclusion}

Our results show that lycopene and caffeine have anti-oxidative effects against renal IR injury. In addition to this, we found that lycopene had higher antioxidant effect when compared with caffeine. We believe that further studies with different doses are needed for caffeine.

Ethical Approval: This study was carried out in accordance with the national health institute guidelines on the use of experimental animals with the permission of Bolu Abant İzzet Baysal University Animal Research Local Ethics Committee (date: 01/11/2018) 2018/29 numbered permission.

\author{
Author Contributions: \\ Concept: A.S. \\ Literature Review: A.S. \\ Design : A.S., T.F. \\ Data acquisition: T.F., G.Z., H.C. \\ Analysis and interpretation: A.S.,,G.Z., H.C., ÖM.Y. \\ Writing manuscript: A.Ş., T.F., ÖM.Y. \\ Critical revision of manuscript: A.Ş., T.F., ÖM.Y.
}

Conflict of Interest: The authors declare that there is no conflict of interest. 
Financial Disclosure: This study has been funded by Bolu Abant Izzet Baysal University Scientific Research Project (Code: 2019.08.03.1413).

\section{References}

1. Ahmadiasl N, Banaei S, Alihemmati A. Combination antioxidant effect of erythropoietin and melatonin on renal ischemia-reperfusion injury in rats. Iran J Basic Med Sci. 2013;16(12):1209-16.

2. Zhang X, Zhou X, Zhang Q, Zhu F. The preventive effects of dexmedetomidine against intestinal ischemia - reperfusion injury in Wistar rats. 2012;(13).

3. Zhou T, Prather ER, Garrison DE, Zuo L. Interplay between ROS and antioxidants during ischemia-reperfusion injuries in cardiac and skeletal muscle. Int J Mol Sci. 2018;19(2).

4. Chen X, Wang CC, Song SM, Wei SY, Li JS, Zhao SL, et al. The administration of erythropoietin attenuates kidney injury induced by ischemia/reperfusion with increased activation of Wnt/ $\beta$-catenin signaling. J Formos Med Assoc [Internet]. 2015;114(5):430-7. Available from: http://dx.doi.org/10.1016/j.jfma.2015.01.007

5. Wang Y, Tian J, Qiao X, Su X, Mi Y, Zhang R, et al. Intermedin protects against renal ischemiareperfusion injury by inhibiting endoplasmic reticulum stress. BMC Nephrol [Internet]. 2015;16(1):1-12. Available from: http://dx.doi.org/10.1186/s12882-015- 0157-7

6. Sadıc M, Atılgan HI, Aydın A, Koca G, Korkmaz M, Karakan $T$, et al. Scintigraphic, histopathologic, and biochemical evaluation of lycopene effects on renal ischemia reperfusion injury in rats. Srp Arh Celok Lek. 2017;145(3-4):153-8.

7. Pektaş A, Gemalmaz H, Balkaya $M$, Ünsal C, Yenisey Ç, Kiliçarslan $\mathrm{N}$, et al. The short-term protective effects of lycopene on renal ischemiareperfusion injury in rats. 18 Turk Urol Derg. 2014;40(1):46-51.

8. Liu YE, Tong CC, Zhang YB, Jin HX, Gao Y, Hou MX. Effect of dexmedetomidine on rats with renal ischemia-reperfusion injury and the expression of tight junction protein in kidney. Int J Clin Exp Med. 2015;8(10):18751-7.

9. Zhao Y, Xin Z, Li N, Chang S, Chen Y, Geng L, et al. Nanoliposomes of lycopene reduces ischemic brain damage in rodents by regulating iron metabolism. Free Radic Biol Med. 2018;124:1-11.

10. Chen F, Sun ZW, Ye LF, Fu GS, Mou Y, Hu SJ. Lycopene protects against apoptosis in hypoxia/reoxygenationinduced H9C2 myocardioblast cells through increased autophagy. Mol Med Rep. 2015;11(2):1358-65.

11. Tong $C$, Peng $C$, Wang $L$, Zhang $L$, Yang $X, X u$, et al. Intravenous administration of lycopene, a tomato extract, protects against myocardial ischemia-reperfusion injury. Nutrients. 2016;8(3):1-13.

12. Kirmizi DA, Baser E, Okan A, Kara M, Yalvac ES, Doganyigit $Z$. The effect of a natural molecule in ovary ischemia reperfusion damage: Does lycopene protect ovary? Exp Anim. 2021;70(1):37-44.

13. Yue R, Xia X, Jiang J, Yang D, Han Y, Chen X, et al. Mitochondrial DNA Oxidative Damage Contributes to Cardiomyocyte Ischemia/Reperfusion-Injury in Rats: Cardioprotective Role of Lycopene. J Cell Physiol. 2015;230(9):2128-41.

14. Lei $X$, Lei $L$, Zhang $Z$, Cheng $Y$. Neuroprotective effects of lycopene pretreatment on transient global cerebral ischemia-reperfusion in rats: The role of the Nrf2/HO- 1 signaling pathway. Mol Med Rep. 2016;13(1):412-8.

15. Li $X Y, X u L$, Lin GS, Li XY, Jiang $X J$, Wang $T$, et al. Protective effect of caffeine administration on myocardial ischemia/reperfusion injury in rats. Shock. 2011;36(3):289-94.

16. Chou WC, Kao MC, Yue CT, Tsai PS, Huang CJ. Caffeine Mitigates Lung Inflammation Induced by Ischemia-Reperfusion of Lower Limbs in Rats. Mediators Inflamm. 2015;2015.

17. Brezová $V$, Šlebodová $A$, Staško A. Coffee as a source of antioxidants: An EPR study. Food Chem. 2009;114(3):859-68.

18. Lee $C$. Antioxidant ability of caffeine and its metabolites based on the study of oxygen radical absorbing capacity and inhibition of LDL peroxidation. Clin Chim Acta. 2000;295(1-2):141-54.

19. Bayramoglu G, Bayramoglu A, Altuner $Y$, Uyanoglu $M$, Colak $\mathrm{S}$. The effects of lycopene on hepatic ischemia/reperfusion injury in rats. Cytotechnology. 2015;67(3):487-91.

20. Schierwagen $C$, Bylund-Fellenius AC, Lundberg C. Improved method for quantification of tissue PMN accumulation measured by myeloperoxidase activity. J Pharmacol Methods. 1990;23(3):179-86.

21. Li Y, Zhong D, Lei L, Jia Y, Zhou H, Yang B. Propofol prevents renal ischemiareperfusion injury via inhibiting the oxidative stress pathways. Cell Physiol Biochem. 2015;37(1):14-26.

22. Sezen ŞC, Işik B, Bilge $M$, Arslan $M$, Çorau FM, Öztürk $L$, et al. Effect of dexmedetomidine on ischemiareperfusion injury of liver and kidney tissues in experimental diabetes and hepatic ischemiareperfusion injury induced rats. Anaesthesia, Pain Intensive Care. 2016;20(2):143-9.

23. Assad OM, Aly Labib DA, Ahmed Rashed L. Dexmedetomidine protects against myocardial ischaemia/reperfusion-induced renal damage in rats. Egypt J Anaesth [Internet]. 2018;34(1):33-9. Available from: https://doi.org/10.1016/j.egja.2017.09.005

24. Kuhad A, Sethi R, Chopra K. Lycopene attenuates diabetesassociated cognitive 20 decline in rats. Life Sci. 2008;83(34):128-34

25. Xue R, Qiu J, Wei S, Liu M, Wang Q, Wang P, et al. Lycopene alleviates hepatic ischemia reperfusion injury via the Nrf2/HO-1 pathway mediated NLRP3 inflammasome inhibition in Kupffer cells. Ann Transl Med. 2021;9(8):631-631.

26. WANG J, FU J, CHEN D. Study on the protective effect of Lycopene on ischemiareperfusion myocardium through Inhibiting the opening of mitochondrial MPTP and the activation of apoptotic pathway. Food Sci Technol. 2021;2061:1-6.

27. Rasheed $\mathrm{H}, \mathrm{Al}-\mathrm{Naimi} \mathrm{M}$, Hussien $\mathrm{N}, \mathrm{Al}-\mathrm{Harchan} \mathrm{N}, \mathrm{Al}-\mathrm{Ku}$ raishy $\mathrm{H}, \mathrm{Al}-\mathrm{Gareeb} \mathrm{A}$. New insight into the effect of lycopene on the oxidative stress in acute kidney injury. Int J Crit Illn Inj Sci. 2020;10(5):S11-6.

28. Zhang F, Xing S, Li Z. Antagonistic effects of lycopene on cadmium-induced hippocampal dysfunctions in autophagy, calcium homeostatis and redox. Oncotarget. 2017;8(27):44720-31.

29. Koul A, Kaur J, Chugh NA. Protective Potential of Lycopene Enriched Tomato Extract against Dexamethasone Induced Hepatic and Renal Damage in Mice. Asian J Res Biochem. 2021;8(3):1-22.

30. Hussien YA, Abdalkadim H, Mahbuba W, Hadi NR, Jamil DA, Al-Aubaidy HA. The Nephroprotective Effect of Lycopene on Renal Ischemic Reperfusion Injury: A Mouse Model. Indian J Clin Biochem [Internet]. 2020;35(4):474-81. Available from: https://doi.org/10.1007/s12291-01900848-7 
31. Kaya C, Karabulut R, Turkyilmaz Z, Sonmez K, Kulduk G, GüIbahar Ö, et al. Lycopene has reduced renal damage histopathologically and biochemically in experimental renal ischemia-reperfusion injury. Ren Fail. 2015;37(8):1390-5.

32. Bedir F, Kocaturk $H$, Turangezli $O$, Sener E, Akyuz $S$, Ozgeris $\mathrm{FB}$, et al. The protective effect of lycopene against oxidative kidney damage associated with 21 combined use of isoniazid and rifampicin in rats. Brazilian J Med Biol Res. 2021;54(8):1-8.

33. Demir EO, Demirtaş CY, Paşaoğlu ÖT. Ratlarda böbrek antioksidan aktivitesi üzerine kafeinin etkileri. Turkish J Biochem. 2016;41(3):216-22.

34. Kosari S, Hemayat-talab R, Arab-ameri E, Keyhani F, Science $\mathrm{S}$, Disorder H. Zahedan Journal of Research in Medical Sciences. 2013;55-8.

35. Kriško A, Kveder M, Pifat G. Effect of caffeine on oxidation susceptibility of human plasma low density lipoproteins. Clin Chim Acta. 2005;355(1-2):47-53.

36. Nikolic J, Bjelakovic G, Stojanovic I. Effect of caffeine on metabolism of L-arginine in the brain. Mol Cell Biochem. 2003;244(1-2):125-8.

37. Kilicdag H, Daglioglu YK, Erdogan S, Zorludemir S. Effects of caffeine on neuronal apoptosis in neonatal hypoxic-ischemic brain injury. J Matern Neonatal Med. 2014;27(14):1470-5.

38. Nilnumkhum A, Kanlaya R, Yoodee S, Thongboonkerd V. Caffeine inhibits hypoxiainduced renal fibroblast activation by antioxidant mechanism. Cell Adhes Migr [Internet]. 2019;13(1):260-72. Available from: https://doi.org/10.1080/19336918.2019.1638691

39. Fernández MJ, López A, Santa-Maria A. Apoptosis induced by different doses of caffeine on Chinese hamster ovary cells. J Appl Toxicol. 2003;23(4):221-4.

40. Al Moutaery K, Al Deeb S, Khan HA, Tariq M, Valadka AB, Narayan RK, et al. Caffeine impairs short-term neurological outcome after concussive head injury in rats. Neurosurgery. 2003;53(3):704-12. 